\title{
Sinicisation vs. Arabisation: Online Narratives of Islamophobia in China
}

\section{Ying Miao*}

Department of Politics and International Relations in Aston University, Birmingham, UK

\begin{abstract}
This article examines the recent rise of Islamophobic narratives in the Chinese cyberspace. Using content analysis of social media headline articles, this article argues that key Islamophobic actors in the Chinese cyberspace have constructed a 'victims and villains' narrative to effectively 'other' Muslim populations in China. By implying that non-Sinicised Muslims are under Arab fundamentalist influences, religious autonomy becomes political betrayal and Islamophobia is legitimised. Elements of Islamophobia is then subsumed in the official narrative calling for ethnic loyalty to the Chinese nation, which presents a unique challenge to the Chinese Party-state as Islamophobic discourses both legitimises statesponsored autocratic control in Muslim regions, but also could potentially bring destabilisation to an already fragile ethnic relationship between Muslim minorities and the Han majority.
\end{abstract}

* Contact: Ying Miao, y.miao2@aston.ac.uk 


\section{Introduction}

The rise of Islamophobia in the West in recent decades is a well-documented phenomenon. Right-wing politicians and political groups in the West have been able to manipulate and amass support by highlighting the so-called 'Muslim problem,' and the idea of Muslims and Islam being a threat to Western values and security is described as the 'green scare' or the 'green peril.' 1 Therefore, Islamophobia implies hatred or animosity aimed at Islam and Muslims. ${ }^{2}$ It is not new: it has been associated with orientalism, whereby the West associated Islam and Muslims with exoticism and negative stereotypes. Contemporary uses of Islamophobia first entered public discourse after the 1997 Runnymede report by the British race relations NGO the Runnymede Trust. ${ }^{3}$ However, like all contested and politicised concepts, Islamophobia is difficult to define.

Although the definition of Islamophobia can be shifting and context-specific, the increasing consensus is that Islamophobia should be seen as a form of cultural racism, where "cultural signifiers are used to manifest essentially fixed characterizations among different groups in society, and these differences are essentially 'insurmountable." 4 This calls upon a "us versus them' belief system where a "homogeneous and static culture with specific and deleterious characterizations" is recognised, and anything that does not fit within the cultural system is rejected. ${ }^{5}$ Contemporary Islamophobia predominantly situates the 'other' within a Western geographical context. Contemporary practices that reflect the idea of an inner threat are visible in migration control, the surveillance of Muslim citizens, and the overall practices of geopolitical empire. ${ }^{6}$ In British newspapers, for example, Muslims are presented as culturally deviant and so a threat to British culture. ${ }^{7}$ Hence, Marranci argues that "Islamophobia is not an unfounded hostility against Islam, but a hostility that has its last raison d'être in the fear of multiculturalism and its consequences."

\footnotetext{
${ }^{1}$ Jens Rydgren, 'Immigration Sceptics, Xenophobes or Racists? Radical Right - Wing Voting in Six West European Countries', European Journal of Political Research 47(6), (2008), pp. 737-65. Matt Carr, 'You Are Now Entering Eurabia', Race \& Class 48(1), (2006), pp. 1-22; Liz Fekete and Ambalavaner Sivanandan, A Suitable Enemy: Racism, Migration and Islamophobia in Europe, (London, Pluto Press, 2009).

${ }^{2}$ Brian Klug, 'Islamophobia: A Concept Comes of Age”, Ethnicities 12(5), (2012), pp. 665-81.

${ }^{3}$ Gordon Conway, Islamophobia: A Challenge for Us All, (London, Runnymede Trust London, 1997); Erik Bleich, 'What Is Islamophobia and How Much Is There? Theorizing and Measuring an Emerging Comparative Concept', American Behavioral Scientist 55(12), (2011), pp. 1581-1600.

${ }^{4}$ Fred Halliday, “Islamophobia' Reconsidered', Ethnic and Racial Studies 22(5), (1999), p893. Sabine Schiffer and Constantin Wagner, 'Anti-Semitism and Islamophobia-New Enemies, Old Patterns', Race \& Class 52(3), (2011), pp. 77-84. Etienne Balibar, 'Is There A 'neo-Racism'?', Race and Racialization: Essential Readings, 2007, pp. 85-88; Samuel P. Huntington, The Clash of Civilizations and the Remaking of World Order, (New York: Touchstone, 1997).

${ }^{5}$ Edward W. Said, Covering Islam: How the Media and the Experts Determine How We See the Rest of the World (Fully Revised Edition), (London, Random House, 2008).

${ }^{6}$ Deepa Kumar, Islamophobia and the Politics of Empire, (London, Haymarket Books, 2012).

${ }^{7}$ John E. Richardson, (Mis) Representing Islam: The Racism and Rhetoric of British Broadsheet Newspapers, vol. 9, (Amsterdam, John Benjamins Publishing, 2004).

${ }^{8}$ Gabriele Marranci, 'Multiculturalism, Islam and the Clash of Civilisations Theory: Rethinking Islamophobia', Culture and Religion 5(1), (2004), pp. 105-17.
} 
Since the September 11 attack, the subsequently declared and US-led high profile 'Global War on Terror' has subsumed focal insurgencies and other 'little wars' waged on Muslims across the globe. ${ }^{9}$ With the rise of right-wing politicians such as Donald Trump, most debates on populist discourses such as Islamophobia in recent years have been focused in contrast to pluralism and democracy, predominantly looking at Anglo-American and European societies. Less attention has been paid to how these views manifest in authoritarian states. This article examines the recent rise of Islamophobic hate speech in the Chinese cyberspace, especially in the context of the renewed emphasis on the Sinicisation of Islam in the official narrative.

Using content analysis of social media headline articles, this article argues that key Islamophobic actors in Chinese cyberspace have constructed a 'victims and villains' narrative to effectively 'other' Muslim populations and cultures in China. Those who are socialised into being Muslims, usually Uyghurs, are portrayed as innocent and deceived victims, thus can be 'awakened' and 'saved' through Sinicisation; whereas those who knowingly take advantage of ethnic policies and religious affirmative action are seen as villains, thus branded as traitors of the Chinese nation. By implying that non-Sinicised Muslims are under Arab fundamentalist influences, religious autonomy becomes political betrayal, and Islamophobia is legitimised. Elements of Islamophobia is then subsumed in the official narrative calling for ethnic loyalty to the Chinese nation, which presents a unique challenge to the Chinese Partystate as Islamophobic discourses both legitimise state-sponsored autocratic control in Muslim regions, but also could bring destabilisation to an already fragile ethnic relationship between Muslim minorities and the Han majority.

\section{Sinicisation of Islam as Official CCP Narrative}

The concept of Sinicisation of Islam was first introduced in the Academic Symposium on Islam in November 1980, in Yinchuan, Ningxia. The idea was controversial at the very beginning, with some scholars applauding and supporting the notion and others criticising it as being historically backward. Since the April 2016 National Religious Work Conference in Beijing, however, Sinicisation of Islam was officially instated as government policy, and all debate regarding the legitimacy and practicability of the concept had ceased. Instead, discourses have emerged in Chinese academia in full support of official Sinicisation, which seeks to legitimise the 'othering' of non-Sinicised Chinese Muslims. For instance, one CASS scholar ${ }^{10}$ wrote:

The Arabs in the peninsula are a backward group lacking in culture... when they conquer a region, they can only offer the locals Islam and the Quran. Everything else they assimilate from local cultures.

\footnotetext{
${ }^{9}$ Abdulkaroom Vakil and Salman Sayyid, Thinking Through Islamophobia: Global Perspectives, (New York, Columbia University Press, 2010).

${ }^{10}$ CASS: Chinese Academy of Social Sciences. CASS is the foremost Party-sponsored social science research institution in China, under the direct supervision of the CCP and the Ministry of Propaganda.
} 
Quoting Engels, he argued that the Arabs were the conquered, whose 'barbaric nature meant they had to assimilate to the better economic conditions of their conquered cultures". ${ }^{11}$

CASS scholars usually argue that historically, Islam was Sinicised successfully. ${ }^{12}$ However, they also warned that contemporary Islam in China is at the risk of Arabisation, with many Chinese Muslims becoming 'spiritually Arab,' and numerous aspects of Chinese Muslim territories taking on Arab features such as the building of Arab-style mosques and the adoption of Arab-Muslim clothing. ${ }^{13}$

In line with the nationalistic 'Chinese sovereignty must be protected' narrative, CASS authors often suggested that if Islam is not Sinicised, then China will end up like Central Asia, where 'domestic peace was disturbed due to an influx of Islamic and foreign funding.' 14 Scholars are very wary of Saudi Arabia in particular, warning that de-Sinicisation of Islam will mean Islamic parts of China will turn into Saudi Arabia, asking, "and how many countries want to be like Saudi Arabia?"15 All foreign influence is labelled extreme, coming from the Wahabi or Salafi sects, who have 'ulterior political motives.' They typically conclude that Islamic fundamentalism is at the root of the spread of the de-Sinicisation and Arabisation of Chinese Muslims, a 'dangerous course' that must be corrected.

In line of such narratives, the continued Sinicisation effort has led to a socio-spatial hierarchy of Muslims in China: those who are most Sinicised and living closest to Han populations are seen as the most acculturated and accepted, such as the urban Hui of China's coastal region, while the ethnically distinct Uyghur living the peripheral regions of Xinjiang away from Han majority areas are seen as at the risk of succumbing to separatism and foreign fundamentalist influence. This is also reflected in the mainstream everyday discourses, which sees Chinese culture as the mundane, and any minority cultures as the exotic. ${ }^{16}$ Influenced by the secular Communist ideology, the Chinese Han usually views religion as anti-modern. ${ }^{17}$ In the case of Islam in particular, it has been reported that the doctrine has been perceived as 'too strict' and 'feudal,' creating 'pious disciples' who, because most of them in Han-dominated regions are

\footnotetext{
${ }^{11}$ Yijiu Jin, “三论伊斯兰教在中国的地方化和民族化 [The Third Debate on Localisation and Nationalisation of Islam in China]', Journal of Northwest University for Nationalities 4(4), (2015), pp. 1-8.

${ }^{12} \mathrm{Weijian} \mathrm{Li}$, ‘伊斯兰教中国化的历史经验与现实分析 [The Historical Experience and Realistic Analysis of the Sinicization of Islam]', Journal of the Central Institute of Socialism 2(2), (2018), pp. 127-33; Yijiu Jin, 'The Localisation and Nationalisation of Islam in China', Study of Islam 1(1), (1995), pp. 1-8; Jianwu Ma and Qixin Song, “伊斯兰教在中国 的本土化探析 [An Exploration of Sinicisation of Islam in China]', Journal of Northwest Minzu University 5(5), (2007), pp. 94-97.

${ }^{13} \mathrm{Li}$, 'The Historical Experience and Realistic Analysis of the Sinicization of Islam].”

${ }^{14}$ Jin, 'The Third Debate on Localisation and Nationalisation of Islam in China].”

${ }^{15}$ ibid.

${ }^{16}$ Jörg Friedrichs, 'Sino-Muslim Relations: the Han, the Hui, and the Uyghurs", Journal of Muslim Minority Affairs 37(1), (2017), pp. 55-79. Margaret Wetherell and Jonathan Potter, Mapping the Language of Racism: Discourse and the Legitimation of Exploitation, (New York, Columbia University Press, 1993).

${ }^{17}$ Lin Yi, 'Culturalism, Education and Islamophobia in China', in Thinking Through Islamophobia: Global Perspectives, (New York, Columbia University Press, 2010), pp. 185-95.
} 
self-employed, are also seen as 'unscrupulous merchants' in favour of profit rather than education. ${ }^{18}$

Similar to the cultural racism argument in the West, there is an element of culturalism in the Islamophobic discourses in China. For instance, Yi argues that 'prejudice or discrimination against ethnic minorities as a whole is ingrained in China's ancient culturalism and manifests itself through shifting discursive repertoires depending on the differing historical circumstances.' ${ }^{19}$ Central to this culturalism is the idea that China was the only true civilisation, and non-Chinese can be legitimised through the civilising effect of (Confucian) education, which further affirms Han superiority. ${ }^{20}$ This fluid, instrumental way of identity construction inevitably lead to the construction of 'others' who are seen as barbaric or inferior. The intrinsic alienness of the other does not matter as much as their willingness to assimilate. Ironically, the ethnogenesis of peripheral groups is likely to develop as a reaction to these civilising discourses or projects. ${ }^{21}$

Xinjiang has witnessed increased securitisation since the 2008 Beijing Olympics, and events and debates surrounding the ethnic issue in Xinjiang have gained prominence in the public domain following the 2014 Kunming attack and the introduction of state re-education camps. $^{22}$ Bolstered by official narrative and policies, Islamophobia has become increasingly prevalent online in the last few years with the central idea that Muslims in China have to pick sides: they must either be Sinicised or Islamicised and Arabised, with the former choice denoting peaceful integration, and the latter choice signalling sinister associations with extremism.

\section{Methods}

This article draws material published by a well-known Islamophobic account on Weibo, with more than 337,000 followers. Although this is by far not the most impressive follower number in Chinese cyberspace, it is worth noting that Islamophobia is not condoned officially in China, and any openly inflammatory content is frequently censored. Indeed, Weibo has made several attempts to ban and delete the account, causing the author to lose followers as he is forced to migrate. However, content that is not openly calling for ethnic violence and conflict do evade censorship, and they remain in wide circulation. The specific account used for this article's analysis is one of the current backup accounts, began in 2016. Using the Weibo headline article function, this account periodically pushes out news and commentary from Islamophobic opinion leaders across the Chinese cyberspace. Thus it serves as a useful

\footnotetext{
${ }^{18}$ Lin Yi, 'Ethnicization Through Schooling: the Mainstream Discursive Repertoires of Ethnic Minorities', The China Quarterly 192, (2007), pp. 933-48.

19 ibid.

${ }^{20}$ James Townsend, 'Chinese Nationalism”, The Australian Journal of Chinese Affairs, 27(27), (1992), pp. 97-130.

${ }^{21}$ Stevan Harrell, Cultural Encounters on China's Ethnic Frontiers, (Seattle, University of Washington Press, 2011).

${ }^{22}$ Sean R Roberts, 'The Biopolitics of China's 'War on Terror' and the Exclusion of the Uyghurs', Critical Asian Studies 50(2), (2018), pp. 232-58; Joanne Smith Finley, 'Securitization, Insecurity and Conflict in Contemporary Xinjiang: Has PRC Counter-Terrorism Evolved Into State Terror?', Central Asian Survey, 38(1), (2019) pp. 1-26,
} 
source to assess key Islamophobic narratives present in the Chinese Internet. For this article, a total of 155 headline articles published between 2016 and 2018 were collected, then coded and analysed using NVivo 12.

\section{The Victim Narrative: The Deceived vs. The Oppressed}

All of the articles sampled have particular recurring key agendas and narrative themes. These agendas can be summarised into two categories: those who have suffered under the evils brought by Islam and Muslims (the victims), and the agents assisting the spread of such evils (the villains). One of the key questions asked by Islamophobic actors in Chinese cyberspace is: if Islam is an evil, then who are its victims? Here, two distinct forms of victim narratives emerge: those who are deceived and trapped by Islamic teachings, usually Uyghur Muslims, and those who are oppressed by the special privileges afforded to Muslim minorities, usually the Han.

In the deceived victim narrative, the Uyghurs are portrayed as an ethnic minority population who have accepted Islamic practices unthinkingly, and lack agency in fighting against "religious extremism" encroaching on their freedom. Consequently, the narrative focuses on the 'awakening' of the Uyghurs, by emphasising the distinction between ethnic and religious identity and reminding them of their overarching Chinese national identity. By doing so, the narrative effectively 'others' the Uyghurs who do choose to subscribe to their Muslim identity, as the choice is seen as un-Chinese.

I want to say to all Uyghur children: you are not born Muslims! You are citizens of the People's Republic of China, and you are the hopes and dreams of the Chinese nation. ${ }^{23}$

These articles often repeat and stress that Uyghurs are not necessarily Muslims, hence throwing into question why Uyghurs have to follow Islamic traditions and practices such as halal. Halal, meaning permissible and originally used to denote 'pure food,' is generally referred to as qingzhen in China, meaning clean and good, and an indication that the product has a Muslim provider. Like halal practices across the world, qingzhen practices are deeply contextualised and represent a constant negotiation between the ethnic identities of the Muslim population, government policies, and the "Islamic"/“Chinese" culture. ${ }^{24}$ While the government seeks to regulate, certify and brand halal and qingzhen, it is, in reality, a term that signifies faith and practices embedded in everyday lives: being Muslim as well as the way of life. ${ }^{25}$ Nevertheless, the authors of the Islamophobic pieces placed a significant emphasis between religious identity and ethnic identity and suggested that Uyghurs accept

\footnotetext{
${ }^{23}$ Xiaogu Wang, ‘我叫王小古, 我孩子名字我做主 [My Name Is Xiaogu Wang, I Shall Decide What I Will Call My Children]', Weibo, October 10, 2018, accessed September 23, 2018, https://www.weibo.com/ttarticle/p/show?id=2309404293375334470051.

${ }^{24}$ Johan Fischer and Yukari Sai, 'Muslim Food Consumption in China: Between Qingzhen and Halal', in Halal Matters: Islam, Politics and Markets in Global Perspective, (London, Routledge, 2015), pp. 170-84.

${ }^{25} \mathrm{Min} \mathrm{Su}$, “捍卫 “清真”: 世界宗教, 迷信与鲁西南回民的伊斯兰想象 [Defending “Qingzhen”: World Religion, Superstition, and Islam Phenomena of Luxinan Huimin]', Religion and Anthropology 00(00), (2012), p6.
} 
religious practices not because of their own volition, but because they are afraid of social ostracisation, thus framing Uyghurs as powerless victims bound by peer pressure. While Uyghur society has been observed to conform to community and peer pressure, the authors imply that religious peer pressure has sinister intentions that are forced upon the impressionable Uyghurs. ${ }^{26}$

Some Uyghurs can say that they are not Muslims, but their way of life still has religious elements. Are they really choosing not to use technology or eat pork because they can't get used to it? Or are they afraid of being punished by some religious law that they themselves did not even choose to subscribe to? ${ }^{27}$

We Uyghurs are kidnapped by our religion because we are afraid of being treated as the odd one out if we don't follow practises such as halal... We just go with the flow. ${ }^{28}$

It is worth noting that these articles often equate extremism with any ostentatious religious practice, especially those seen as un-Chinese. This is in line with state counter-extremism laws issued after 2018, which named the wearing of Burkas, 'unnatural growth of beards,' and 'overtly religious names' as extremist behaviours. ${ }^{29}$ Drawing on similar interpretations, religious beliefs and practices are often referred to as 'chains,' 'shackles' or 'cages,' which the Uyghurs were unable to break free by themselves.

We need to differentiate between ethnic traditions and religious traditions, and break free from the cage of 'halal thought'. ${ }^{30}$

Everyday I feel like I am wearing an invisible shackle, and I can't breathe. ${ }^{31}$

Despite the repeated emphasis on the distinction between ethnic and religious practices, the writers of such pieces never made clear what 'non-religious ethnic traditions' were. Instead, the narrative focused on how religious practices were socialised and never questioned. It is portrayed that the spread of such religious practices is recent developments: authors often

\footnotetext{
${ }^{26}$ Ildikó Bellér-Hann, Community Matters in Xinjiang, 1880-1949: Towards a Historical Anthropology of the Uyghur, (London, Brill, 2008); Joanne N Smith Finley, The Art of Symbolic Resistance: Uyghur Identities and Uyghur-Han Relations in Contemporary Xinjiang, (London, Brill, 2013).

${ }^{27}$ Eysa Raxman, ‘不做宗教习俗的傀儡 [Do Not Become Puppets of Religion]', Weibo, September 16, 2018, accessed September 23, 2018, https://www.weibo.com/ttarticle/p/show?id=2309404284899656920836.

${ }^{28}$ Murat Kurban, “一名维吾尔族发声亮剑: 消除陃习, 做移风易俗的共产党员 [a Ughyur Announces: We Should Destroy Old Habits and Be Secular CCP Members]', Weibo, September 20, 2018, accessed September 23, 2018, https://www.weibo.com/ttarticle/p/show?id=2309404286130752214751.

29 ‘新疆维吾尔自治区去极端化条例 [Xinjiang Uyghur Autonomous Region Regulation on De-Extremification]', Peoples Daily, April 1, 2017, accessed September 23, 2018, http://xj.people.com.cn/n2/2017/0330/c186332-29942874.html.

${ }^{30}$ Mohammad Ismail, ‘认清’泛清真化”的背后阴谋 [Beware of the Conspiracy Behind "Pan-Halal"]’, Weibo, September 22, 2018, accessed September 24, 2018, https://media.weibo.cn/article/amp?id=2309404286989057824514.

${ }^{31}$ Ayjamal Ahmad, “冲破民族堡垒：嫁给汉族胖子是我最幸福的事 [Overcoming the Ethnic Barrier: Marrying a Han Person Is the Best Thing I Did]', Weibo, October 13, 2018, accessed September 23, 2018, https://www.weibo.com/ttarticle/p/show?id=2309404294631209729165.
} 
made nostalgic comments about their childhood where they did not follow halal practices strictly and could freely mix with their Han neighbours.

I was born in the 1970s... my neighbours back then were all Han. During the holidays we invited everyone around, so we had Han food as well. My father didn't have this halal or non-halal differentiation and we enjoyed both halal food and Han food, as we liked. We had no differences with the Han, we were a family albeit with some language barriers. ${ }^{32}$

While the claims of free intermingling made in these nostalgic pieces can be called into doubt (for instance, social, spatial and symbolic segregation has been in place since the 1980s,) nevertheless they strove to emphasise the ideas that Xinjiang had always belonged to China, and all Chinese were one and the same, which fits in with the state-sanctioned narrative of a unified and harmonious China. ${ }^{33}$ The authors then go on to argue that in recent years, a 'religious atmosphere' has overtaken the Uyghur community, which allowed extremist ideas to proliferate. One author warned:

If we do not discard religious practices, our ethnic group will be kidnapped by religion, our tradition will be replaced by religious tradition, and we will lose ourselves and become puppets of religion. ${ }^{34}$

By arguing that halal and other religious practices are non-ethnic and non-traditional, the authors have drawn the link between halal practices and extremism, and others Islamic practices as non-mainstream, and hence non-Chinese.

If Uyghurs want to assimilate into the big family of the Chinese nation, then we have to say no to extremist ideas... assimilate into the mainstream, not asking the mainstream to accommodate us. Leave halal to religion, and return freedom to the people! ${ }^{35}$

These narratives mainly present Uyghurs as having no agency or proactive awareness in following religious practices, hence allowing them to be portrayed as 'innocent.' This is particularly important because there is evidence to suggest that Uyghurs communities have been activating and exaggerating certain religio-cultural differences (the practice of halal in particular) as a means of ensuring symbolic, spatial and social segregation from the Han, which was observed as early as $1995 .{ }^{36}$ However, such behaviour does not fit the official

\footnotetext{
${ }^{32}$ Mijiti Qadir, “一名维吾尔族: 推翻清真围墙, 别让饮食禁忌祸害了我们 [From a Uyghur: Down with the Halal Wall, Do Not Let Us Become Poisoned by Religious Food Abstinence]', Weibo, October 3, 2018, accessed September 24, 2018 , https://www.weibo.com/ttarticle/p/show?id=2309404291094471932405.

${ }^{33}$ Finley, The Art of Symbolic Resistance: Uyghur Identities and Uyghur-Han Relations in Contemporary Xinjiang.

${ }^{34}$ Raxman, “不做宗教习俗的傀儡 [Do Not Become Puppets of Religion].”

${ }^{35}$ Ismail, '[Beware of the Conspiracy Behind "Pan-Halal"]."

${ }^{36}$ Ildikó Bellér-Hann, 'Temperamental Neighbours: Uighur-Han Relations in Xinjiang, Northwest China', Imagined Differences: Hatred and the Construction of Identity 5, (2002), p. 57; Joanne N. Smith, 'Making Culture Matter': Symbolic, Spatial and Social Boundaries Between Uyghurs and Han Chinese', Asian Ethnicity 3(2), (2002), pp. 153-74.
} 
narrative on ethnic harmony and the Chinese-ness of all ethnic groups. Grassroot narratives cannot counter the official discourse and suggest that Uyghurs are naturally un-Chinese such attempts are seen as inciting ethnic hatred and will be immediately removed. In order to promote Sinicisation, then, agency must be removed from the Uyghurs, and any elements of symbolic protests downplayed. The deceived, innocent victim narrative thus allows the Uyghurs to be 'purified,' modernised and 'enlightened,' so long as they are Sinicised. Such narratives mirror the supporting discourses behind the instalment of state re-education camps in Xinjiang, where those 'lost to extremist ideas' are helped to 'find their way back' and provided with 'employment trainings in order to build a better life.'37

On the other hand, in the oppressed narrative lies the most common grievance of Islamophobic authors in the Chinese cyberspace: that the Han people, the majority ethnic group of China, has been putting up with unreasonable demands of religious affirmative action, and suffering under the state-sanctioned preferential policies for ethnic minorities. Here the focal point of complaint is not against the Uyghur minority but rather the Hui.

Unlike the Uyghurs, whose genetic makeup and appearance are closer to that of the Turkish and Central Asians, the Hui look very similar to the Han. Religion then becomes their ethnic marker: in these narratives, the Hui are represented by their Islamic belief and their Islamic practices. Specific attention is given to how the Han, who are often the majority ethnic group in any social setting, have to tolerate religious taboos and practices of the Hui:

China is the biggest consumer of pork in the world, and yet here we have halal flights and halal trains [to Hui populated regions] that don't serve pork at all. This is not ethnic unity! If ethnic minorities have special dietary requirements, then they should tend to it themselves, rather than asking the majority population to compromise. ${ }^{38}$

In this topic, the authors appropriate the idea of 'rights' and argue that if Muslim minorities have a right to enjoy halal, then the Han majority must have a right to ask for non-halal food.

Some people say this is for ethnic unity. Are you saying that in order to achieve ethnic unity, the Han must follow the Hui in not eating pork, following halal rules, and follow whatever habit the Hui have? This is not tolerance, respect or unity, this is oppression! ${ }^{39}$

\footnotetext{
${ }^{37}$ Xiaoming Liu, 'Harmony in Xinjiang Is Based on Three Principles', Financial Times, August 21, 2018, accessed September 26, 2018, https://www.ft.com/content/05a81682-a219-11e8-85da-eeb7a9ce36e4.

${ }^{38}$ Han Eagle, ‘猪都到哪儿去了一一主流媒体谈猪色变, 原因在哪里? [Where Did the Pigs Go -- Why Are Mainstream Media So Afraid of Pigs?]', Weibo, February 12, 2018, accessed September 25, 2018 https://www.weibo.com/ttarticle/p/show?id=2309404206497788755984.

39 Jinghong, “宁夏大学虽大, 却容不下一个世俗餐厅? [the Grand Ningxia University Cannot Even Tolerate a Non-Halal Restaurant]', Weibo, August 15, 2017, accessed September 25, 2018, https://www.weibo.com/ttarticle/p/show?id=2309404141131012171183.
} 
The authors reject the idea that halal provisions in Muslim minority populated regions are meant to promote ethnic harmony and emphasise that the Han people have already been losing out economically as Muslim minorities receive certain halal food subsidies which the Han are not privy to. One article specifically attempted to calculate how much halal subsidies were given to Muslim populations in China and implied the money could be better spent elsewhere such as on children's education in deprived areas.

If you argue that Han can also eat halal, then I must ask you: why don't everyone regardless of their ethnicity get beef and lamb subsidies? Surely you can't have all the privileges? ${ }^{40}$

Similarly, as the food was cheaper in the subsidised halal restaurants in universities, the authors questioned whether this was unfair on Han university students, who had a limited budget.

Halal restaurants are cheaper by a third and have bigger portions... to save money, I went to a halal restaurant once. In order to avoid having meat that was religiously treated, I only had the vegetable dishes, which cost me 3.5 yuan. If I went to a normal restaurant, [the same dish] would have cost me 7.7 yuan. Who is subsidising this? ${ }^{41}$

The focal point of concern in these narratives was the oppressive nature of such ostentatious religious practice. Special attention is given to eye-grabbing cases where the concept of halal is misused, such as halal bread, halal water, and in one high-profile case, where a Hui patient demanded that he could only receive 'halal blood' from another Hui donor. Such use of halal symbols and concepts in products that are otherwise not in the halal purview are called 'panhalal' or 'spread of halal' [泛清真化] and is warned to be extremist.

I have appealed to the public many times, and I don't know what to say anymore. The root of terrorism lies in religious extremism, which is pan-halal, and panIslamic practices! I will say no more! ${ }^{42}$

Such loose-fitting definitions of extremism echo the state's narrative on Uyghur terrorism, as the state counter-extremism guidelines explicitly state pan-halal as an extremist

\footnotetext{
40 ibid.

${ }^{41}$ Zihan, ‘某大学网友爆料: 清真食堂比普通食堂便宜三分之一 [Netizens Reveal: Halal Canteens Are Cheaper Than Non-Halal Canteens!]', Weibo, September 15, 2017, accessed September 25, 2018, https://www.weibo.com/ttarticle/p/show?id=2309404152355179349234.

${ }^{42}$ Ai Lijiang, “极端分子最后的下场就是下火狱, 包庇纵容极端分子的人就是自掘坟墓! [All Extremists Go to Hell, and Those Who Tolerate Extremism Are Digging Their Own Graves!]', Weibo, August 24, 2017, accessed September 25, 2018, https://www.weibo.com/ttarticle/p/show?id=2309404144333413586801.
} 
manifestation, for providing means to 'reject or interfere with secular life. ${ }^{43}$ Regardless of their accuracy, such narratives are prone to become self-fulfilling prophecies. ${ }^{44}$

It is worth noting that the accusatory pieces written from the Han point of view are not usually directed at the Uyghurs, as these are considered harmful to ethnic unity. Proactive admissions of guilt from reformed Uyghurs, however are a common tactic in the confessional pieces. Reform and repent pieces are also more likely to come from state and traditional media, as they serve to celebrate the success of the civilising mission. Grievance and accusatory posts, by contrast, are more likely to be censored, as they highlight ethnic tension and often call existing policies into question. In the model Uyghur pieces, Sinicised Uyghurs would note how unfair it was that the Han people were always accommodating minority lifestyles, thus legitimising the author's argument that religious tolerance and affirmative action means sacrifices for the Han.

In Xinjiang, whenever there is a gathering, if there is one ethnic minority then everyone will go to a halal restaurant for him or her. We just take it for granted, thinking that they have no dietary restrictions so it doesn't matter where they eat. But this is completely ignoring their sacrifices. ${ }^{45}$

I've seen a lot of Han cadres calling themselves by Uyghur names in Uyghur regions, to be closer to the people there. But most Uyghurs would think it's deeply disrespectful to ask them to have a Han name. This is narrow-minded, nationalistic, and even extremist. ${ }^{46}$

Another narrative tactic is drawing out how disenfranchised the Han has become in the face of positive discrimination for ethnic minorities.

For Han citizens living in the North West minority populated regions, they wouldn't get into conflict with ethnic minorities, and instead hide as far as they can. Why? They do not feel confident in law enforcement's ability to make a fair judgement, when the other party are ethnic minorities. Not only that, but they also worry that they will be charged with crimes of disrupting ethnic harmony. ${ }^{47}$

Ethnic policies regarding university entrance exams and civil service entrance exams attract particular criticism, where affirmative action for ethnic minorities is seen to have caused Han

\footnotetext{
${ }^{43}$ People's Daily, ‘新疆维吾尔自治区去极端化条例 [Xinjiang Uyghur Autonomous Region Regulation on DeExtremification].”

${ }^{44}$ Sean Roberts, 'Imaginary Terrorism? The Global War on Terror and the Narrative of the Uyghur Terrorist Threat', The Institute for European, Russian and Eurasian Studies (IERES), Elliott School of International Affairs, 2012.

${ }^{45}$ Yusuf Abdurixit, ‘朋友, 你不必专门为我找清真餐厅 [Friends, You Don't Have to Find Halal Restaurants Just for Me]’, Weibo, August 28, 2018, accessed September 25, 2018, https://www.weibo.com/ttarticle/p/show?id=2309404278120151680116.

${ }^{46}$ Wang, ' [My Name Is Xiaogu Wang, I Shall Decide What I Will Call My Children].”

47 Jinghong, “民族团结”不是违法犯罪的护身符 [Ethnic Unity’ Should Not Be an Amulet for Protecting Crime]” Weibo, August 3, 2017, accessed September 23, 2018, https:/www.weibo.com/ttarticle/p/show?id=2309404136787781010700.
} 
children to lose out. In an open letter written to the Guizhou government, parents of Han children cited that $44.96 \%$ of all university entrance exam takers in Guizhou in 2018 benefited from affirmative action ethnic policies, with points added to their final score. They claim that such policies encourage ethnicity fraud, where parents deliberately ask to change their kid's ethnicity category in order to benefit from the points-added scheme. ${ }^{48}$ In another viral news piece, it was revealed that a Han student in Guizhou dropped from first place to number 20 in the exam score rankings after all points-added calculations were made, having been side-lined by ethnic minority students. The article appealed to "save the Han kids!", as this was seen to destroy the upward mobility chances of the Han students. ${ }^{49}$ In another commentary, the author suggested that the affirmative action policies were creating a castelike system in ethnic minority regions:

Martyrs who sacrificed their lives for the Party, for the people and the country, can only have extra points added to their children's university entrance exam scores, for one generation. The ethnic minorities, however, can enjoy extra points for generations to come, and become in essence life peers in our society through their ethnic minority identity! Are the blood of martyrs worth less than a piece of paper proving a person's ethnic identity? This is an invisible caste system taking root in China! ${ }^{50}$

Unlike the deceived Uyghurs, the oppressed Han are portrayed to be in full awareness of their circumstances. It is suggested that the Han are naturally tolerant and have been tolerant for years, and they only chose to speak out because tolerance has now turned into injustice.

For forty years, the Han people have tolerated unfair ethnic policies. As the majority ethnic group they have to be sacrificial, and understanding. However, some people keep challenging their bottom lines and threaten their survival, even kidnap their kid's future! The Han people will not stand this any more, they are forced to speak out $!^{51}$

Overall, the narrative logic for the victim narrative can be briefly summarised as follows:

\footnotetext{
${ }^{48}$ Han Eagle, ‘关于尽快调整高考加分政策维护贵州省 高考公平公正的诉求信 [a Letter of Appeal to Adjust the Awarding of Bonus Points to University Entrace Examinations: We Must Make Sure the Exam Is Fair for the Guizhou Province]', Weibo, August 4, 2018, accessed September 23, 2018, https://www.weibo.com/ttarticle/p/show?id=2309404269333705563538.

${ }^{49}$ Qin Han, ‘救救汉族孩子 [Save the Han Kids!]', Weibo, August 14, 2018, accessed September 23, 2018, https://www.weibo.com/ttarticle/p/show?id=2309404273032184097330.

${ }^{50}$ Han Eagle, ‘关于尽快调整高考加分政策维护贵州省 高考公平公正的诉求信 [A Letter of Appeal to Adjust the Awarding of Bonus Points to University Entrance Examinations: We Must Make Sure the Exam Is Fair for the Guizhou Province]."

${ }^{51}$ Qin Han, '[Save the Han Kids!].”
} 


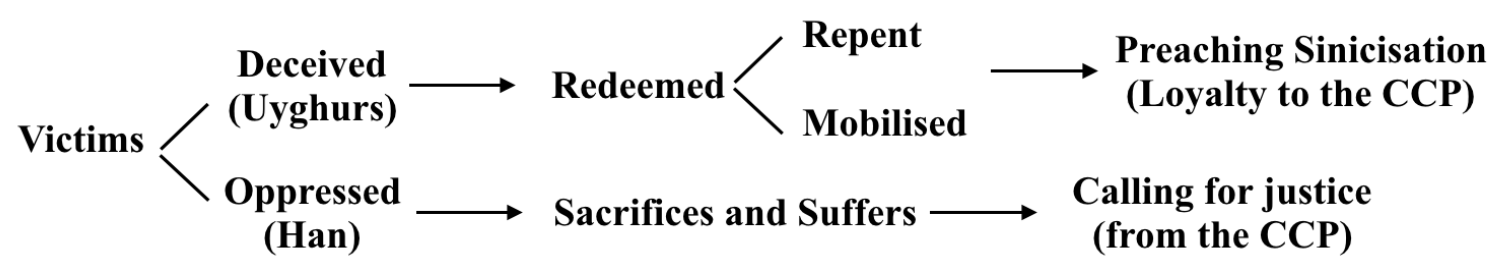

Figure 1: The Victim Narrative

\section{The Villains Narrative: Who is to Blame?}

While Islamophobic narratives are characterised by the hatred and animosity towards Islam and Muslims, the villains of the Islamophobic narrative in the Chinese cyberspace is more nuanced. According to the official Party narrative, Muslim ethnic minority populated regions are primarily threatened by Three Evils [三股势力], which means 'terrorism, separatism, and extremism', and Two-Faced Persons [两面人], a term used to describe those people who proclaim loyalty to the CCP in public, yet secretly work against the regime in private. The Three Evils, presumed to originate from foreign soil, are the masterminds behind Two-Faced Persons, who are portrayed as often having foreign connections or sponsors.

As members of the socio-political elite, Chinese academics and politicians are among the most frequently attacked 'villains.' The embedded assumption is that as members of the elite, politicians and academics should protect Han interests and put the Han majority population first. Any deviation from this role immediately puts into doubt their loyalty to the Han, the $\mathrm{CCP}$, and the Chinese nation. These narratives are essentially populist as they suggest that the elite class have betrayed the will of the people.

In one commentary, the authors attacked a Chinese academic, Professor Zhang Haiyang of Minzu University of China, who questioned the CCP's Sinicisation policy in Xinjiang and expressed concerns over the loss of Uyghur language after the introduction of mandatory mandarin lessons for the Uyghurs. By voicing such concerns, Professor Zhang was immediately put into the opposing ideological camp, which in this case, was the 'Three Evils.'

Professor Zhang is the brainpower of China's ethnic policy. He should be contributing to the peace and stability of the country, and instead he expresses extremist views like the terrorist group overseas. This makes one doubt what kind of stance the professor takes when doing research! $!^{52}$

\footnotetext{
${ }^{52}$ Anxi Jiedushi, ‘中央民大教授张海洋：你是中国政府的智囊，还是分裂分子的智囊? [Professor Zhang: Are You a Think Tank for the Chinese Government, or Are You a Think Tank for Separatists?]', Weibo, August 5, 2017, accessed September 23, 2018, https://www.weibo.com/ttarticle/p/show?id=2309404137464922013242.
} 
In another instance, when history books were updated to replace the word 'barbarian' with 'ethnic minorities,' the authors attacked academia, criticising and labelling all Chinese academics as 'wolves with savage hearts.' They claimed that this was ideological warfare, aimed at 'wiping the slate clean' and paving the way for barbarian invasion and domination of the Han.

These wolves have infiltrated us and they are trying to destroy our national identity and cultural belonging. They are destroying our historical pride and honour! Those Han people who called the barbarian invasions as 'ethnic minorities migrations', they are numb and do not feel pain. Do they feel no shame in front of their slaughtered ancestors? ${ }^{53}$

Not only were the authors concerned about 'ideological pollution and infiltration,' but they also attempted to raise 'empirical evidence' that practices such as halal led to de facto ethnic segregation on campus. Examples were given on how halal food is heavily subsidised, nonhalal food was limited in choice, and how the provision of halal establishments led to the physical separation of students. Such policies were often equated with extremism, with the assumption that such exclusionary practices bred radicalisation.

Many university offices publicly segregate student canteens... from halal canteens to no non-halal food allowed, to Muslim only seats and Muslim only canteens. We can see how extremist forces infiltrate our socialist campuses. ${ }^{54}$

Whereas academics are often criticised in how they influence and enforce ethnic policy in higher education settings, the grievances against politicians are often directed at their inability to correct perceived wrongs. For instance, several articles raised the issue of the apparent de-Sinicising of local Mosques, where Arabic signs and plaques have been erected in place of Chinese ones. In the case of Yangzhou, the author wrote:

What is more abominable [following the construction of the Arabic signs], is when Yangzhou citizens made an enquiring call to the Bureau of Religious Affairs, the person responsible said this is religious freedom, and not within their administrative purview! ${ }^{55}$

The author questioned the purpose of the sudden de-Sinicisation, asking, "what is it trying to prove or achieve?", implying that there are sinister forces at hand. Furthermore, the author

\footnotetext{
${ }^{53}$ Han Eagle, ‘历史虚无主义真的好吗？ [Is Historical Nihilism Actually Good for Us?]', Weibo, July 26, 2017, accessed September 23, 2018, https://www.weibo.com/ttarticle/p/show?id=2309404133726467531379.

${ }^{54}$ Jinghong, “种族隔离: 从’清真氛围不浓厚”的大学食堂开始 [Ethnic Segregation: Starting From the University Canteens Are Are Not "Halal Enough"]', Weibo, June 20, 2017, accessed September 23, 2018, https://www.weibo.com/ttarticle/p/show?id=2309404120653069479199\&infeed=1.

${ }^{55}$ Han Eagle, “扬州为何如此献媚伊斯兰教去中国化? [Why Is Yangzhou So Eager to Help the De-Sinicisation of Islam?]', Weibo, August 18, 2017, accessed September 23, 2018, https://www.weibo.com/ttarticle/p/show?id=2309404142167139475489.
} 
questioned the role of the officials in failing to safeguard against de-Sinicisation in Yangzhou:

Why did the Bureau of Religious Affairs and the Planning Committees allow the construction of such religious symbols? Or did they just turn a blind eye? Is there negligence in this $?^{56}$

Similarly, when Muslim ethnic conflicts are reported in the media, the authors often complain that law enforcement fails to prioritise Han people or protect Han interests, and politicians fail to answer Han grievances. Instead, the justice apparatus is biased towards ethnic minorities, who are seen as unrepentant troublemakers:

The incompetent politicians and bureaucrats are so used to just appeasing the side who can gather the most number of people and make the most noise, rather than deal with things fairly, justly and transparently. This means extremist groups get special privileges, and of course they just keep making trouble. ${ }^{57}$

This ties in with the Han as victims narrative, where authors claim that the Han are always losing out in ethnic conflicts because they are more law-abiding, and play by the rules, whereas the Muslim minorities do not subscribe to the idea of the rule of law. By using anecdotal evidence and focusing on crimes caused by Muslims in their articles, the author 'others' Muslim minorities and further stresses the two ideological camps that exist in the narrative: the mainstream (Han) and the extremist other (Muslim).

Even if the Han netizens scream hoarse in their protest online and ring the Bureau office phones off the hook, we would not attack the government buildings, because we understand the rule of law. Unfortunately, the quiet and law-abiding group always loses out. The politicians and officials just have to lay low and pretend to be deaf and mute for a few days, until the Internet moves on, and voila, all is well again! $!^{58}$

Like other populist discourses, the Islamophobic narrative in Chinese cyberspace also views the Chinese media with distrust and often contempt. It is assumed that, like academics, the media has a role in influencing policy and the general populace. As a part of the mainstream (i.e., Han) culture, they must prioritise Han interests, and any hint of preferential treatment given to minorities are viewed with extreme suspicion. In a series of articles, the authors showed how state media outlets such as China Central Television (CCTV) and Xinhua News Network (Xinhua) had avoided the use of 'pig' and 'pork' when talking about Chinese new year traditions, a large part of which involves the procurement of pork for festivities. Allegedly, in light of heightened ethnic tensions in the year 2014, the media had changed the

\footnotetext{
${ }^{56}$ Han Eagle, ‘从淮南某寺事件谈政府與情导控 [The Huainan Temple Incident and Government Public Opinion]', Weibo, August 22, 2017, accessed September 23, 2018, https://www.weibo.com/ttarticle/p/show?id=2309404136425929967518.

57 Jinghong, “Ethnic Unity' Should Not Be an Amulet for Protecting Crime.”

58 ibid.
} 
mention of pork to other types of meat such as beef and lamb, and in some instances, forwent the mention of meat entirely. The authors named this phenomenon "swinophobia.":

Swinophobia is extremism, and any believers who support it are extremists. Any non-believers who support this are accessories to separatists and terrorists. ${ }^{59}$

Having immediately marked the media as extremists in this case, the authors went on to explain why they think the media have acted in this way, portraying the media as a powerless and cowering institution enabling the advance of extremism in Chinese society:

Traditional media and official new media are so afraid of pigs because they are afraid of the power of religious extremists. They clamoured to have the pigs removed because the media are afraid of them trouble-makers. The media are cowards, and they have self-censored for too long - they are used to licking the boots of extremists. ${ }^{60}$

Similarly, when CCTV made a documentary series tracing some Chinese surnames to Arab origins, the authors strongly refuted the claim and criticised the media for selling the Han out. In another video where CCTV showed Chinese descendants living in Kazakhstan, the authors similarly expressed outrage as they argued that these people were descendants of Han traitors and were historically 'evicted from China' and should not be celebrated. They concluded that:

We have so many Two-Faced Persons in the media and propaganda departments... they appear to work for ethnic harmony on the surface, but in reality they are trying to wipe out the historical memory of our national heroes...Doesn't their conscience hurt? The media should have a moral bottom line $!^{61}$

Unlike the victim narrative, where the deceived and oppressed are portrayed as having very little to no agency and power in the spread of Islamic extremism, the villains narrative portrays these groups as villains precisely because it is assumed these groups do have the power and agency to stop the spread of extremism, but they have betrayed their people and the Chinese nation as they have either chosen to not act on their power, or misused their power for the opposing camp. Thus, there is a strong sense of guilty conviction in this narrative, which effectively frames the villainous groups as enemies of the Chinese people.

\footnotetext{
${ }^{59}$ Han Eagle, '[Where Did the Pigs Go -- Why Are Mainstream Media So Afraid of Pigs?].”

60 ibid.

${ }^{61}$ Jinghong, ‘央视某些人, 是蚌还是坏? [China Central Television: Stupid or Evil?]’, Weibo, May 18, 2017, accessed September 23, 2018, https://www.weibo.com/ttarticle/p/show?id=2309404108659729811838.
} 


\section{Legitimising Islamophobia: Tactics and Approaches}

\section{Reformed Uyghurs as Exemplars}

A specific type of article stands out in the overall Islamophobic articles sampled, which can be described as 'model Uyghur' or 'reformed Uyghur' pieces, in the sense that they are written by successfully Sinicised Uyghurs, serving as role models and exemplars. Among the articles sampled, more than a quarter were supposedly confessional or conversion pieces written by Uyghur authors. These articles follow a typical structure:

\section{Deceived $\rightarrow$ Redeemed (by the CCP) $\rightarrow$ Repent $\rightarrow$ Preaching Sinicisation}

\section{Figure 2: The model Uyghurs narrative}

As the previous section has detailed, the pieces start with the proclamation that the Uyghurs were deceived and have followed religious practices and even extremist practices unknowingly. They are redeemed by the CCP, often after having moved to bigger, Han majority populated cities, or joined the state apparatus and coming into contact with other Party members.

Following the 'awakening,' the Uyghur authors would often repent his or her previous mistakes, to mark their transition to a more 'modern, forward way of thought.' In a letter written by a Uyghur father to his daughter, for example, the father repents that he has been infiltrated by extremist religious thought despite his best attempts:

You were always an active kid and wanted to try out new things when we went out. I had been picky about your food, telling you that these were not halal and you can't have them. Now that I've come around, I realise how I was helping separatists and extremists in spreading their ideas! When you asked me why we can't eat pork, I couldn't explain it, so instead said offhandedly 'because you will grow pig ears and pig's nose!' Now I deeply regret my words. I was not bringing you up right! ${ }^{62}$

The Uyghurs authors would often remind their peers how much the CCP has helped the development of the Uyghur regions such as Xinjiang, and that they must appreciate the good life that they have now. This type of narrative echoes the CCP's performance legitimacy, where the Party's legitimate claim to rule is underlined by the economic growth and social development it is able to achieve.

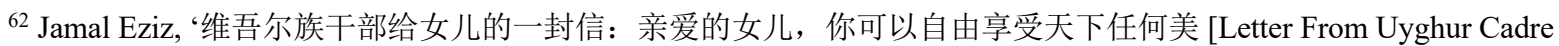
to Daughter: Dear Daughter, You Can Enjoy Any Beauty in the World]', Weibo, October 8, 2017, accessed September 23, 2018, https://www.weibo.com/ttarticle/p/show?id=2309404292805638932949.
} 
The CCP has done so much for Xinjiang... [long paragraph of official statistics on Xinjiang's development] All of these policies aimed at improving people's livelihoods are the only one in the world, no other political party has ever been able to achieve this anywhere else. This is ironclad proof that the CCP is good for the people. Without the CCP, how can the people of Xinjiang live good lives as they do today? Isn't this worth our gratitude, and forever loyalty? ${ }^{63}$

Ironically, economic development in Xinjiang both demonstrates the state's power and also reveals hidden tensions in society, especially as increasing numbers of Han people move to Xinjiang for large infrastructure projects. ${ }^{64}$ It was found in 2011 that Uyghurs earn 31 percent less than Han ${ }^{65}$ and that the regional labour market continues to skew towards Han domination of high-status and high-wage positions, and Uyghur domination of low-status and low-wage positions. ${ }^{66}$ Thus, scholars have argued that the tensions between the Uyghur and Han are not primarily due to ethnic tensions, but rather due to 'growing Uyghur perceptions of socio-economic inequalities between themselves and the Han. ${ }^{67}$ In being deliberately panegyric of CCP's economic achievements, these model Uyghur pieces are downplaying the nuanced reality of economic inequality in Xinjiang, and instead seeking to emphasise the paternalistic role of the Chinese state so that the larger debate of Uyghur-Han relations can be subsumed into the state nationalistic discourse.

These narratives also present a simplistic division of ideological camps, where those who are unappreciative and not loyal to the CCP are immediately branded 'defectors' or 'devils,' and will come to regret their decision.

Our motherland is like a giant protecting the 1.3 billion people living in it. Those who don't value such a good life and illegally cross the border to join extremist groups will only experience homelessness, loneliness, and endless defeat abroad... only then they will truly understand the greatness of our nation. Think! Our great nation has given us a heavenly life, so how can we abandon our motherland and follow the devils instead? ${ }^{68}$

Often these pieces end on a high, hopeful note, with the author expressing how proud they are of being conformed and Sinicised. Sinicisation is equated frequently with modernisation and forward-thinking, as well as assimilation in national identity.

\footnotetext{
${ }^{63}$ Mohammad Bekri, “维吾尔族干部在反恐维稳工作中要打头阵[Uyghur Cadres Have to Charge at the Front Lines for Anti-Terrorism Work]', ThePaper.Cn, March 5, 2018, accessed September 23, 2018, https://www.thepaper.cn/newsDetail_forward_1655035.

${ }^{64}$ Martin I. Wayne, 'Inside China's War on Terrorism', Journal of Contemporary China 18(59), (2009), pp. $249-61$.

${ }^{65}$ Xiaowei Zang, 'Uyghur-Han Earnings Differentials in Ürümchi’, The China Journal 65(5), (2011), pp. 141-55.

${ }^{66}$ Reza Hasmath, 'What Explains the Rise of Majority-Minority Tensions and Conflict in Xinjiang?', Central Asian Survey 38(1), (2019), pp. 46-60.

${ }^{67}$ Smith, "Making Culture Matter': Symbolic, Spatial and Social Boundaries Between Uyghurs and Han Chinese."

${ }^{68}$ Xinjiang Daily, ‘五问维吾尔青年 [Five Questions for the Uyghur Young]', Weibo, March 31 2017, accessed September 23, 2018. https://www.weibo.com/ttarticle/p/show?id=2309404091419328436263.
} 
Right now, all the comrades in our bureau are like one family. All of our canteens are now non-halal...we have broken the backward traditions in our ethnic practices and we have caught up with the times. We all feel that no matter our ethnicity, we are all Chinese! ${ }^{69}$

Finally, these Model Uyghur pieces are written by Uyghur cadres who also actively encourage other Uyghur cadres to mobilise the masses and identify any possible Two-Faced Persons among them, suggesting that those who stay silent on the matter are automatic accessories to the separatists.

Uyghur cadres must lead the charge on the war against separatism... we need to mobilise the masses, draw a firm line between themselves and the extremists, actively offer any useful clues as to where to catch the separatists...Anyone who doesn't lead the charge or speaks out at this critical time is helping the separatist movement, and will become enemies of the people. ${ }^{70}$

There are a variety of ways for Uyghur cadres to lead the charge and demonstrate loyalty to the CCP, and writing such a piece to be disseminated is one of them. Indeed, there is some evidence that Uyghurs would submit these confessional pieces to avoid political trouble. ${ }^{71}$ Other demonstrations include adopting Han names, giving up halal practices, and promoting mixed marriages between Han and Uyghurs. While there is no definite proof that these pieces are actual heartfelt works of Sinicised Uyghurs, this is not the only evidence of Uyghur-led Sinicisation effort. Uyghurs who are educated through the Han education route (i.e., attending Mandarin-taught schools), for example, often become teachers and teach Han and state-sanctioned ideas in Uyghur schools. ${ }^{72}$ The usage of these confessional/conversion pieces, therefore, add to the author's arsenal in legitimising the 'innocent yet deceived' victim narrative they have constructed for the Uyghurs.

\section{Seeking Paternalistic Protection from Party State Narratives}

Furthermore, whereas Islamophobic discourses in the West focuses on the supposed cultural deviance of Islam and the Muslims to legitimise their claims, Islamophobia in the Chinese cyberspace emphasises the supposed political deviance of Muslim minority groups. Although the narrative is still underpinned by racist stereotypes, smear campaigns and conspiracy theories, all of these elements are ultimately legitimised or delegitimised through reference to official Party narratives. Xi Jinping's speeches, Chinese law and constitution, and even

\footnotetext{
${ }^{69}$ Qadir, ' [From a Uyghur: Down with the Halal Wall, Do Not Let Us Become Poisoned by Religious Food Abstinence].”

${ }^{70}$ Bekri, '[Uyghur Cadres Have to Charge at the Front Lines for Anti-Terrorism Work]."

${ }^{71}$ Rachel Harris and Aziz Isa, 'Islam by Smartphone: Reading the Uyghur Islamic Revival on WeChat', Central Asian Survey 38(1), (2019), pp. 61-80.

72 James D Frankel, “Apoliticization”: One Facet of Chinese Islam." Journal of Muslim Minority Affairs 28(3), (2008), pp. 421-434; Dru C Gladney, 'Cyber-Separatism, Islam, and the State in China', in Identity Conflicts, (London, Routledge, 2017), pp. 113-32.
} 
Marxism-Leninism have all been employed as a legitimising tool for their grievances. For instance, religious practices are placed opposite civil law:

China is ruled by law, Uyghurs are Chinese citizens and should obey Chinese law... Why should our life be kidnapped by religious rules? Sisters and brothers of the Uyghur ethnicity! We must not make the mistake of taking religious rule as law again. ${ }^{73}$

The Party Constitution is selectively cited as reasons why Uyghur cadres must denounce their religion:

As a Party member, we have to be atheists... and only subscribe to MarxismLeninism Maoism and Deng Xiaoping Thought according to the Party Constitution. ${ }^{74}$

The authors also legitimised their attack on the media by framing it as a loyalty test to the CCP:

Whether the media dares to mention pigs is a good test, it should be the standard test to see whether they are loyal to the Party. Are they accessories to the Three Evils, or are they true Chinese patriots? Let's see if they are brave enough to talk about pigs! ${ }^{75}$

When the authors wanted to criticise politicians for failing to protect Han interests, they often did so by quoting the official speeches of higher-ranked officials and Xi Jinping, concluding that the politicians at the local level have failed to follow Party directives, thus legitimising their grievance. When netizens protested about the construction of a mosque in the city centre of Huainan, the local government censored much of the online protest, causing a significant backlash. In a popular commentary that followed, the authors quoted Xi Jinping's speech in a cybersecurity workshop, where he said 'we must be patient and tolerant with the netizens and listen to their voices'. This is followed by another quote from the editor from the People's Daily, the Party mouthpiece publication, who said 'propaganda departments must not simply delete public opinion online and pretend nothing has happened.' Using these two speeches as legitimising cornerstones, the author went on to give policy advice to the local government, advocating a 'more inclusive policy decision process that takes into account netizen's feelings. ${ }^{, 76}$

\footnotetext{
${ }^{73}$ Wang, ‘ [My Name Is Xiaogu Wang, I Shall Decide What I Will Call My Children].”

${ }^{74}$ Urumuqi Public Prosecutor Office, “乌鲁木齐市检察机关决战”泛清真化”大会：不获全胜 决不收兵 [Urumuqi Prosecutor's Office Launches Battle Against 'Pan-Halal': We Will Not Retreat Until We Have Victory]', Guancha, October 10, 2018, accessed October 21, 2018, https://www.guancha.cn/politics/2018_10_10_474942.shtml.

${ }^{75}$ Han Eagle, '[Where Did the Pigs Go -- Why Are Mainstream Media Are Afraid of Pigs?]."

${ }^{76}$ Han Eagle, '[The Huainan Temple Incident and Government Public Opinion].”
} 
As it is still the official Party guideline to promote ethnic unity, Islamophobic actors in the Chinese cyberspace cannot frame their grievances to be overtly targeting Muslims on a religious or ethnic basis (although these posts are not uncommon, they are often quickly censored). Instead, the only type of grievance against Islam and Muslim minorities that can survive in the Chinese cyberspace are the ones that challenge their loyalty to the Party-state. Therefore, the core elements of Islamophobia are often subsumed in the official narrative calling for ethnic loyalty to the Party-state, and by extension, the Chinese nation.

\section{Conclusion}

This article has focused on grassroot Islamophobic narratives in the Chinese cyberspace, to illustrate how these discourses have developed certain patterns and sought paternalistic protection from the grander, official narratives of ethnic harmony and stability to legitimise their political grievances and messages. A key element found in both official and grassroot discourse on Islam in China is that both have framed Sinicised Islam to be peaceful Islam while non-Sinicised Islam to be Arabised, fundamentalist, separatist, and militant Islam. These discourses exhibit essentially populist features in that they focus on the negative labelling and 'othering' of Muslims and their related religious practices. By creating a narrative of victims and villains, they portray that Islam is quintessentially foreign, unChinese, and so must be distrusted. Through the use of model Uyghur conversion pieces, they also advocate that the only way for Muslim minority populations to assimilate into Chinese society is to Sinicise and warns that any attempt that emphasises their religious identity and practices could be seen as a political and national betrayal.

The end product of Islamophobic discourses and the social practices of discrimination and stigmatisation of Muslims in the West is the 'act of physical racial violence carried out by individuals. ${ }^{77}$ Although racial violence is less common in China, Islamophobic discourses circulating on Chinese social media websites have contributed towards offline discriminatory and trolling behaviour such as burying pig's heads in front of mosque grounds. ${ }^{78}$ In light of increasing tensions over the rise of identity politics across the world, nascent Islamophobia in Chinese society should not be overlooked. Such grassroot Islamophobic discourses both seek legitimisation from and in turn further legitimises, CCP's iron-fist rule of Muslim populated regions such as Xinjiang. Islamophobic actors in the Chinese cyberspace have the potential to stir up volatile and latent hatred in the populace and bring further destabilisation to an already fragile ethnic relationship between Muslim minorities and the Han majority.

\section{Acknowledgement}

\footnotetext{
77 Schiffer and Wagner, 'Anti-Semitism and Islamophobia-New Enemies, Old Patterns.”

${ }^{78}$ Gerry Shih, 'Islamophobia in China on the Rise Fuelled by Online Hate Speech', The Independent, April 10, 2017, accessed October 27, 2018, https://www.independent.co.uk/news/world/asia/islamophobia-china-rise-online-hate-speechanti-muslim-islam-nangang-communist-party-government-a 7676031.html.
} 
The author would like to thank David Schak and the two anonymous reviewers for their valuable comments and suggestions.

\section{Notes on the Contributor}

Dr Ying Miao is a Lecturer in the Department of Politics in Aston University, Birmingham, UK. Her research interests include Chinese politics and social change, populism in comparative contexts, and comparative development between China and the West. Her articles have appeared in the Journal of Current Chinese Affairs and Asian Studies Review, and her monograph, Being Middle Class in China, was published by Routledge in 2017. 